\title{
The high-fertility cycle: How timely pregnancies in one lactation may lead to less body condition loss, fewer health issues, greater fertility, and reduced early pregnancy losses in the next lactation
}

\author{
E. L. Middleton, T. Minela, and J. R. Pursley* \\ Department of Animal Science, Michigan State University, East Lansing 48824
}

\begin{abstract}
Body condition loss during early lactation varies among cows in the herd and is associated with future health and reproductive outcomes. The objective of this study was to gain a greater understanding of the relationship between previous calving interval and body condition change during the first $30 \mathrm{~d}$ in milk (DIM) and their relationship to subsequent fertility and health variables and sex ratio at birth. Dry cows and heifers $(\mathrm{n}=851)$ from a single farm entered the study approximately $25 \mathrm{~d}$ before the due date. They were evaluated and given a body condition score on a 1-to-5 scale with 0.1-point increments weekly until parturition. Body condition score was assessed within 1 wk of parturition and then again 27 to 33 DIM. Previous calving interval, gestation length, periparturient health events (giving birth to twins, dystocia, retained placentas, ketosis, metritis, and displaced abomasum), sire net merit (\$), and milk data were used for each cow as recorded in PCDART (Dairy Records Management Systems, Raleigh, NC) by the herd managers. Longer previous calving intervals were related to greater body condition at parturition and body condition loss during the first 30 DIM. A $75 \%$ greater proportion of cows with a calving-to-pregnancy interval shorter than 130 $\mathrm{d}$ maintained or gained body condition during the first 30 DIM compared with cows with calving-to-pregnancy intervals longer than $130 \mathrm{~d}$. Multiparous cows that maintained or gained body condition $(\mathrm{n}=144)$ had greater pregnancies per AI following first service compared with cows that lost body condition $(\mathrm{n}=577)$ during the first 30 DIM when health events were considered or removed. When cows with health events were considered, multiparous cows that maintained or gained body condition had a greater percentage pregnant by 130 DIM compared with cows that lost body condition
\end{abstract}

Received October 10, 2018.

Accepted January 23, 2019.

*Corresponding author: pursleyr@msu.edu
(67 vs. $55 \%$; $\mathrm{n}=522$ ). Cows that lost body condition during the first 30 DIM regardless of health events experienced greater pregnancy loss $(\mathrm{n}=224)$ between 35 and $60 \mathrm{~d}$ after first AI (0.0 vs. 6.7\%) compared with cows that maintained or gained body condition ( $\mathrm{n}=$ 69) during that period. Based on data in this study from a single herd, maintaining a cycle of pregnancy before 130 DIM may reduce the amount of body condition lost after the next parturition, enhance subsequent pregnancies per AI, and reduce the possibility of early pregnancy loss. We refer to this phenomenon as the high-fertility cycle.

Key words: body condition loss, fertility, periparturient disease, pregnancy loss, sex ratio at birth

\section{INTRODUCTION}

Physiological changes in early lactation can alter subsequent fertility of lactating dairy cows (Carvalho et al., 2014). It is common for dairy cows to lose body condition after parturition. Multiple studies demonstrated that low body condition or loss of body condition creates fewer pregnancies per AI $(\mathbf{P} / \mathbf{A I})$ at first service (Domecq et al., 1997; Moreira et al., 2000; Santos et al., 2009). Furthermore, Carvalho et al. (2014) reported a significant increase in $\mathrm{P} / \mathrm{AI}$ if cows gained or maintained body condition during the first $3 \mathrm{wk}$ postpartum.

Cow health affects reproductive success (Ribeiro et al., 2013). Body condition is a key indicator of cow health and a useful tool in monitoring the nutritional state of dairy cattle (Heuer et al., 1999). Changes in body condition in early lactation are associated with postpartum health events such as twinning, dystocia, retained placenta $(\mathbf{R P})$, ketosis, metritis, and displaced abomasum (Ruegg and Milton, 1995; Gillund et al., 2001; Berry et al., 2007b). Dohoo and Martin (1984) reported that the presence of a single clinical disease may predispose cows to other diseases in current and future lactations, particularly mastitis and metabolic diseases. 
Pryce et al. (2001) indicated that poor reproductive performance and low body condition may extend the length of calving interval. A cow's body condition during the first 30 DIM can be used as an indicator of calving interval (Pryce et al., 2000). Calving interval is an important reproductive variable with economic consequences for dairy cows. The ideal calving interval for most cows was determined to be 12 to 13 mo (Morris, 1971). Body condition score profiles are mirror images of lactation curves (Berry et al., 2006; Roche et al., 2007), so it is reasonable to believe that cows with an extended calving interval may become overconditioned, resulting in a greater loss of body condition following the next parturition (Ruegg and Milton, 1995; Heuer et al., 1999) and an increased mortality risk (Shahid et al., 2015).

There is a need for a greater understanding of the association between previous calving interval, BCS, fertility, and health in the next lactation. The main objective of this study was to gain a greater understanding of the association between previous calving interval and body condition change during the first 30 DIM and their relationship to subsequent fertility and health variables and sex ratio at birth. We hypothesized that time to pregnancy in the previous lactation would be associated with body condition change, health, and fertility variables in the subsequent lactation. A secondary objective was to describe how body condition changes and other measurements in first-parity cows were associated with fertility and health variables.

\section{MATERIALS AND METHODS}

\section{Cows, Housing, and Materials}

This trial was conducted from March 2016 to June 2017 on a commercial Holstein dairy farm (Nobis Dairy Farm, St. Johns, MI). The farm milked approximately 1,000 dairy cows 3 times a day, with a daily average milk production of $42 \mathrm{~kg} /$ cow per day. Lactating cows were fed a TMR once a day with free access to feed and water and were housed in a 4-row freestall barn with sidewall curtains and fans. The TMR consisted of corn, wheat, and alfalfa silages and corn-soybean meal-based concentrates formulated to meet nutrient recommendations for lactating dairy cows (NRC, 2001). Three basic lactating cow diets were fed to (1) early-lactation, (2) first-parity, and (3) multiparous cows. Two dry cow diets were fed to (1) cows entering the dry period and (2) cows within 3 wk of their calving date. Both dry cow diets consisted of primarily corn silage but included grass hay when entering the dry period and straw plus concentrates in the close-up ration. Cows entering third or greater lactations and any cows with twins received calcium supplementation at calving. The Institutional Animal Care and Use Committee at Michigan State University approved all animal handling and procedures.

\section{Experimental Design}

Heifers before first calving were included in this study even though the primary objective of this study dealt with multiparous cows. Thus, dry cows following first and subsequent lactations and heifers ( $\mathrm{n}=$ 851) entered the study approximately $25 \mathrm{~d}$ before their due date. Cows and heifers were evaluated and given a BCS on a 1-to-5 scale with 0.1-point increments weekly until parturition. This scale was adapted from the 0.25-point increments described by Edmondson et al. (1989). The BCS within 1 wk of parturition was used in the analyses. All cows were then assessed another BCS on the same scale at 27 to 33 DIM $(\mathrm{n}=787)$. All cows on this farm received first timed AI at 75 to 81 DIM using the farm-managed G6G/Ovsynch program as follows: $\mathrm{PGF}_{2 \alpha}, 2 \mathrm{~d}-\mathrm{GnRH}, 6 \mathrm{~d}-\mathrm{GnRH}, 7 \mathrm{~d}-\mathrm{PGF}_{2 \alpha}$, $56 \mathrm{~h}-\mathrm{GnRH}$, and $16 \mathrm{~h}-\mathrm{AI}$. Cows were diagnosed for pregnancy $35 \mathrm{~d}$ post-AI by the herd veterinarian using ultrasound. If diagnosed as not pregnant, cows received AI 22 d later following retreatment with G6G/Ovsynch. An additional pregnancy diagnosis was performed 60 d post-AI by the herd veterinarian using ultrasound. Fetal sex was determined (Curran, 1992) 60 to $66 \mathrm{~d}$ post-AI ( $\mathrm{n}=493$ ) using transrectal ultrasonography (SonoSite MicroMaxx $10-5 \mathrm{MHz}$ linear array probe, SonoSite, Bothell, WA). Pregnancy was reconfirmed using a pregnancy-associated glycoprotein ELISA assay $120 \mathrm{~d}$ post-AI and, if pregnant, again $188 \mathrm{~d}$ post-AI (AntelBio, NorthStar Cooperative DHI Services, Grand Ledge, MI). Fetal sex was determined with ultrasound at 60 to $66 \mathrm{~d}$ post-AI in all cows. However, analyses of the association between body condition loss during the first 30 DIM and sex ratio used calving information and fetal sex at 60 to $66 \mathrm{~d}$ post-AI in cows that left the herd before parturition. Only cows with singletons were included in sex ratio analyses $(\mathrm{n}=466 ; \mathrm{n}=400$ with calving records and $n=66$ with fetal sexing).

Previous calving interval, gestation length, periparturient health events (including giving birth to twins, dystocia, RP, ketosis, metritis, and displaced abomasum), sire net merit (\$), and milk data were used for each cow as recorded in PCDART (DRMS, Raleigh, $\mathrm{NC})$ by the herd managers. Milk production information was collected every $2 \mathrm{wk}$ (NorthStar Cooperative DHI Services). Milk production information nearest 30 and 60 DIM was chosen for analyses. The presence of 
bovine leukemia virus and Johne's disease was determined by an ELISA assay (AntelBio, NorthStar Cooperative DHI Services).

\section{Statistical Analyses}

All information was recorded in a Microsoft Excel (Microsoft Corp., Redmond, WA) spreadsheet for organization before statistical analysis. A total of 851 primiparous (34\%) and multiparous (66\%) cows received a BCS at calving. A total of 160 cows left the herd following first BCS. Of these, 64 cows did not receive a second BCS, 20 did not receive first AI, and 76 left the herd following first AI. More than half $(52.50 \%)$ of the $18.4 \%$ of cows that were culled or died did so before first $\mathrm{AI}$ at 75 to $81 \mathrm{DIM}$. This distribution agrees with hazards calculated by De Vries et al. (2010) where hazards peaked at 10 to $30 \mathrm{DIM}$ and were at the lowest around 70 DIM. Hazards of culling gradually increased after that point (De Vries et al., 2010). Some analyses related to only pregnancy outcomes removed cows with health events $(\mathrm{n}=126)$. When analyzing data for net merit (\$), there were only 695 cows with that information in PCDART. Milk fever was not considered in analyses due to only 4 cows being treated for this periparturient disorder during this study.

Binomial variables were analyzed using a generalized linear mixed model fitted with the GLIMMIX procedure of SAS (version 9.4, SAS Institute Inc., Cary, NC). All models considered class of body condition change or BCS at calving, or BCS at 30 DIM, parity, and their interactions as fixed effects and season (month of calving), sire net merit (\$), health events, and 30 and 60 DIM milk production as random effects. Nonsignificant interactions were then removed in a stepwise fashion from the model. Only random variables with $P<0.20$ remained in the model. Predicted probabilities of pregnancy were computed using the LOGISTIC procedure of SAS. In some cases, season and health events were considered fixed effects. Selected analyses used CochranMantel-Haenszel chi-squared analyses using the FREQ procedure of SAS for the effect class of body condition change on pregnancy outcomes. Survival curve analyses were performed using the LIFETEST procedure of SAS. Log rank $P$-values were used for significance.

Continuous variables were analyzed using the CORR procedure of SAS. These included univariate analyses of the relationship between previous calving interval and body condition at calving, previous calving-topregnancy interval, and subsequent gestation length.

Gestation lengths that were shorter than $250 \mathrm{~d}$ were removed from any analyses relating to gestation length. The percentage of single male calves was compared by the chi-squared goodness-of-fit test with an expected population value of $54 \%$ obtained from a study with 12,325 calves born to multiparous Holstein-Friesian cows (Ryan and Boland, 1991).

\section{RESULTS AND DISCUSSION}

The Britt hypothesis (Britt, 1992) states that cows undergoing body condition loss in early lactation have lower progesterone and poorer fertility than cows that maintain or gain body condition. Data (Britt, 1992) supporting this hypothesis delineated 2 groups of cows that either lost body condition or maintained, and to some extent gained, body condition following parturition. This was clearly the case in the current study, although a greater proportion of cows lost body condition compared with Britt (1992). Percentage of cows that lost body condition $(80 \% ; \mathrm{n}=629)$ was greater $(P=0.001)$ than percentage of cows that maintained or gained $(20 \%$; $\mathrm{n}=158)$ body condition during the first 30 DIM in the current study. Outcomes from this study in this single herd of cows describe how cows that become pregnant early in lactation have a greater likelihood of maintaining or gaining body condition early in lactation versus cows that become pregnant later in lactation. This in turn increased chances of $\mathrm{P} / \mathrm{AI}$ at first service and reduced postpartum health issues and early pregnancy loss. We refer to this as the highfertility cycle.

\section{Relationships Between Previous Calving Interval and Body Condition Changes During the First 30 DIM}

Longer previous calving intervals were related to greater body condition at parturition (Figure 1) and body condition loss during the first 30 DIM (Figure 2). Berry et al. (2006) demonstrated that BCS profiles are mirror images of lactation curves where cows start to gain body condition later in lactation when their milk production plateaus or decreases. Multiparous cows with longer previous calving intervals gained more body condition in late lactation and thus had greater body condition at calving.

Cows with a calving-to-pregnancy interval shorter than $130 \mathrm{~d}$ had a $75 \%$ greater chance of maintaining or gaining body condition during the next lactation compared with cows with calving-to-pregnancy intervals longer than $130 \mathrm{~d}$ ( 28 vs. $16 \% ; P=0.001 ; \mathrm{n}=475)$. It was clear in this herd that timing of pregnancy in one lactation may play an integral role in what happens with body condition at calving and subsequent changes during early lactation. Using 130 DIM as a reference aligns closely with Meadows (2005). That study determined that in order for individual cows to maintain a 13-mo calving interval they cannot be open for more 
than 115 DIM. It seems logical to use fertility programs at first AI to control days to first service while ensuring high P/AI (Bello et al., 2006; Souza et al., 2008) and an aggressive resynchronization program (Fricke, 2002; Giordano et al., 2013) to maximize a cow's chances to conceive before 130 DIM. Poor fertility at first and second AI clearly extends calving intervals past 130 DIM and reduces dairy farm profit (Dijkhuizen et al., 1984; Britt, 1985). Increasing chances for pregnancy for first and second AI increase the chance that cows will calve at a body condition that reduces the chances for body condition loss early in lactation. This is the first step in the process of cows maintaining a high-fertility cycle.

\section{Relationships Between Body Condition at Calving and Body Condition Changes During the First 30 DIM}

Greater body condition at parturition resulted in greater loss of body condition during the first 30 DIM $(\mathrm{n}=787 ; P<0.01)$. Primiparous cows had greater body condition at parturition $(3.01 \pm 0.02$ vs. $2.78 \pm$ $0.01 ; \mathrm{n}=787 ; P<0.01)$ and lost more body condition $(-0.15 \pm 0.01$ vs. $-0.11 \pm 0.01 ; \mathrm{n}=787 ; P<0.01)$ compared with multiparous cows. Ruegg and Milton (1995) and Roche et al. (2007) also reported that cows with greater BCS at parturition lost more condition. Berry et al. (2006) and Roche et al. (2007) both reported primiparous cows having greater body condition at calving than multiparous cows. Interestingly, $20 \%$ of the cows in this study did not experience body condition loss. This was similar to the $18 \%$ that de Vries and Veerkamp (2000) reported but very low compared with the average of $58 \%$ for 2 herds in Carvalho et al. (2014). Interestingly, these herds were utilizing a fertility program (Double Ovsynch) for first AI, but it was not clear whether this had been part of the historical management of the herd. Herds in the Carvalho et al. (2014) study used bST. Both of these management strategies, if used in the previous $2 \mathrm{yr}$, could have had an effect on body condition at parturition. It appears that one of these herds may have already been in a high-fertility cycle for a long enough time to shift a greater percentage of cows to maintaining or gaining body condition during early lactation.

There was no relationship between class of body condition change and parity $(\mathrm{n}=787 ; P=0.29)$. Berry et al. (2006) found that third-parity cows lost more body condition. Ruegg and Milton (1995) found no significant effect of parity on body condition change.

Cows that lost body condition had greater milk production at 30 DIM $(\mathrm{n}=720 ; P=0.01)$ and 60 DIM (n $=684 ; P=0.001)$ compared with cows that maintained or gained body condition (Figure 3). The magnitude of body condition loss was positively associated with milk production at $30 \mathrm{~d}(P=0.02)$ but not $60 \mathrm{~d}(P=0.51)$. Greater body condition loss has been previously associated with higher peak milk yields (Berry et al., 2007a). There may be tradeoffs from an economic perspective, and it is not clear whether they favor cows that maintained or gained body condition during the first 30 DIM that work their way into a high-fertility cycle. Cows that maintain or gained would likely have fewer

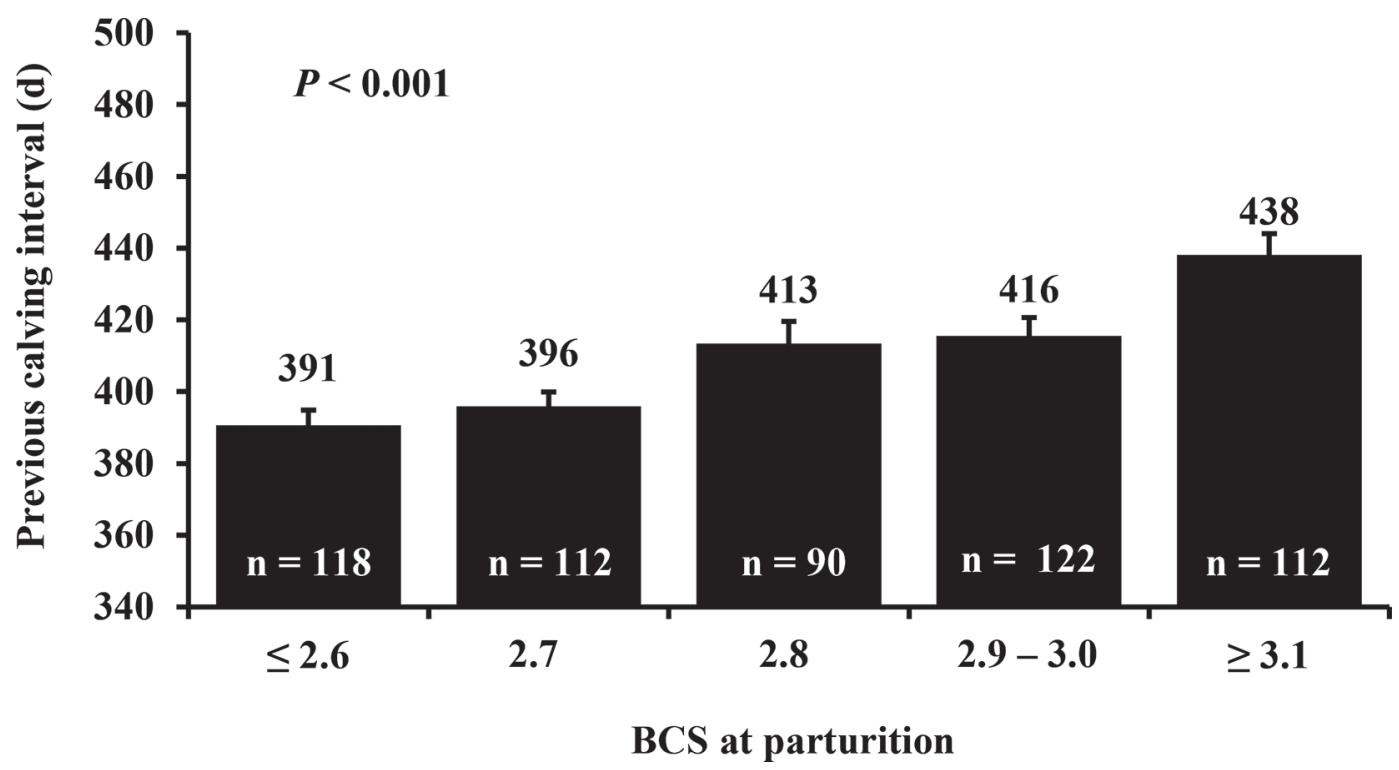

Figure 1. Relationship between average previous calving interval (d) for multiparous lactating Holstein dairy cows and BCS evaluated $\leq 1$ wk before parturition. Cows were evaluated on a 1- to 5-point scale in 0.1-point increments. Data are shown as mean \pm SEM. 


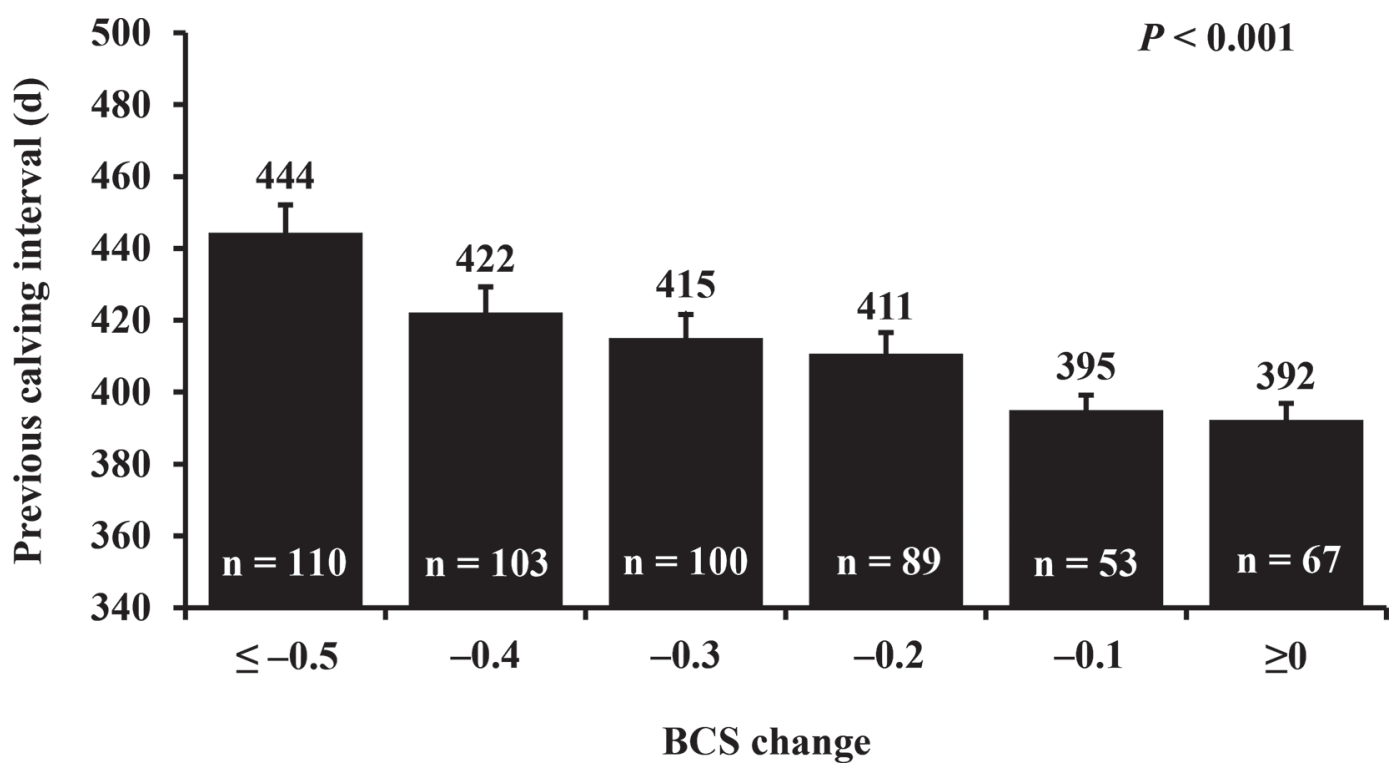

Figure 2. Relationship between average previous calving interval (d) and body condition change evaluated $\leq 1$ wk before parturition and 27 to $33 \mathrm{~d}$ postpartum in multiparous lactating Holstein dairy cows. Data are shown as mean $\pm \mathrm{SEM}$.

days in late lactation and less chance of being treated for health issues and being culled. However, cows in the group that maintained or gained body condition (MGBC) may also have less peak milk based on milk production near 60 DIM (Figure 3).

Both primiparous $(\mathrm{n}=262 ; P=0.002)$ and multiparous $(\mathrm{n}=525 ; P=0.02)$ cows that calved in the first 4

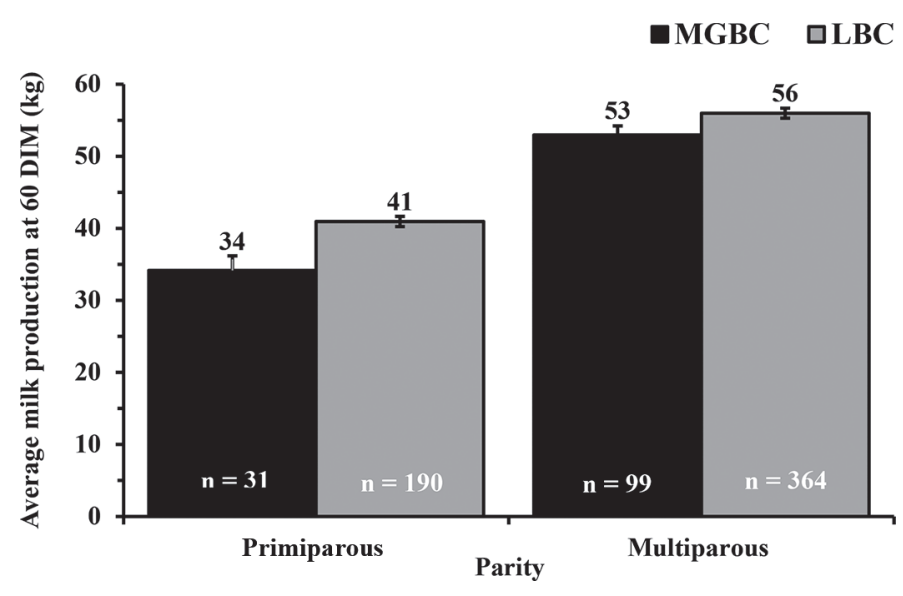

Figure 3. Relationship between primiparous and multiparous lactating Holstein dairy cows that maintained or gained body condition (MGBC; $\mathrm{n}=130$ ) or lost body condition (LBC; $\mathrm{n}=554$ ) during the first 30 DIM and average milk production at 60 DIM (range $=53-67$ d). Significance between body condition change classes and parity was as follows: primiparous MGBC versus primiparous $\mathrm{LBC}, P=0.004$; multiparous $\mathrm{MGBC}$ versus multiparous $\mathrm{LBC}, P=0.03$; primiparous MGBC versus multiparous MGBC, $P<0.001$; primiparous $L B C$ versus multiparous LBC, $P<0.001$; primiparous MGBC versus multiparous LBC, $P<0.001$; primiparous LBC versus multiparous MGBC, $P<0.001$. mo of the year had a greater probability of losing body condition compared with cows that calved the rest of the year. This relationship was likely the result of cold stress in Michigan during these months. Thus, there are clearly other factors that create variability in body condition at parturition and body condition loss early in lactation that can negatively or positively affect the high-fertility cycle.

There was a relationship between body condition change during the first 30 DIM and sire net merit $(\$ ; P=0.05 ; \mathrm{n}=759)$ when only parity was in the model. Greater sire net merit increased the probability of maintaining and gaining body condition during the first 30 DIM. Primiparous cows had greater sire net merit values than multiparous cows $(P<0.001)$, but there was no interaction between class of body condition change and parity $(P=0.91)$.

\section{Relationships Between Body Condition Change During the First 30 DIM and P/Al in Dairy Cows}

Multiparous cows that maintained or gained had greater $\mathrm{P} / \mathrm{AI}$ following first service compared with cows that lost body condition during the first 30 DIM when cows with health events were considered $(P=0.02 ; \mathrm{n}=$ 577 ) or removed ( $\mathrm{n}=461$; Figure 4$)$ from the analyses. Multiparous cows that maintained or gained also had a greater percentage of cows that were pregnant by 130 DIM (64 vs. $51 \% ; P=0.04 ; \mathrm{n}=334$ ). Primiparous cows did not have this relationship when cows with health events were considered $(P=0.43 ; \mathrm{n}=144)$ or 
removed ( $\mathrm{n}=134$; Figure 4) from the analyses. Removing cows with health events from this analysis reduces confounding in the relationship between body condition loss and fertility and argues that body condition loss during the first 30 DIM may have a direct physiological effect on ovarian development or uterine involution at time of first AI. Carvalho et al. (2014) also detected a difference in $\mathrm{P} / \mathrm{AI}$ in favor of cows that maintained or gained body condition, although the differences were substantially greater than they were in this study. This is likely because a larger proportion of cows actually maintained or gained body condition in the Carvalho et al. (2014) study. Santos et al. (2009) also reported reduced P/AI when cows lost body condition. Carvalho et al. (2014) found that the average calving-to conception interval was longer for cows that lost body condition than for cows that maintained or gained body condition. A reason for reduced fertility in the cows that lost body condition during the first 30 DIM could be related to the effect of negative energy balance on subsequent circulating concentrations of progesterone. Villa-Godoy et al. (1988) indicated that the longer the negative energy balance was during the first 100 DIM, the greater the chances of having lower progesterone during the second and third estrous cycles. Cows at first AI in the present study would correlate to approximately the third estrous cycle. It is possible that the cows that lost body condition during the first 30 DIM had lower average circulating concentrations of progesterone.

Overall, primiparous cows $(\mathrm{n}=274)$ had greater $\mathrm{P} /$ AI than multiparous cows $(\mathrm{n}=493)$ at first AI (Figure 4). Similarly, Carvalho et al. (2014) and Santos et al. (2009) reported higher P/AI for primiparous cows compared with multiparous cows. There was no difference in $\mathrm{P} / \mathrm{AI}$ for primiparous cows in the MGBC and loss of body condition (LBC) groups, but multiparous cows had greater P/AI in the MGBC group versus the LBC group (Figure 4). Carvalho et al. (2014) reported a difference in $\mathrm{P} / \mathrm{AI}$ in multiparous cows that maintained, gained, or lost body condition. This difference was also detected in primiparous cows. Domecq et al. (1997) concluded that loss of BCS contributed to conception failure in multiparous but not primiparous cows.

There was a linear relationship between body condition loss and P/AI at second $(\mathrm{n}=213)$ and third $(\mathrm{n}=$ 98) $\mathrm{AI}$ in cows that lost body condition but not in cows that maintained or gained. Cows with greater body condition loss during the first 30 DIM had reduced $\mathrm{P}$ / AI (second AI, $P=0.02$; third AI, $P=0.03$ ). Thus, it appears that the greater the percentage of cows that maintain or gain body condition during early lactation, the greater the chances of pregnancy at first and subsequent AI. Overall, survival analysis indicated that DIM to pregnancy was influenced by class of body condition change during the first 30 DIM and parity (Figure 5). Cows that maintained or gained body condition became pregnant sooner in lactation compared with cows that lost body condition during the first 30 DIM. Once again, this appears to drive the high-fertility cycle from lactation to lactation.

\section{Relationships Between a Single BCS at Calving or 30 DIM and P/AI}

There was no relationship between body condition at parturition and first $\mathrm{AI} \mathrm{P} / \mathrm{AI}(\mathrm{n}=721 ; P=0.12)$. This agrees with results published by Gillund et al. (2001) and Pryce et al. (2001) but not Santos et al. (2009). In addition, there was no relationship between BCS at 30 $\mathrm{DIM}$ and first $\mathrm{AI} \mathrm{P} / \mathrm{AI}(P=0.21 ; \mathrm{n}=721)$. Moreira et al. (2000) observed lower P/AI in cows with low BCS at the initiation of Ovsynch $63 \pm 3$ DIM. Typically, dairy cows in negative energy balance do not stop losing body condition until 50 to 100 DIM (Ruegg and Milton, 1995; Pryce et al., 2001).

There was no relationship between milk production at 30 DIM $(\mathrm{n}=664 ; P=0.50)$ or $60 \operatorname{DIM}(\mathrm{n}=638$; $P=0.46)$ and first AI P/AI. Month of parturition did not predict $\mathrm{P} / \mathrm{AI}$ at first $\mathrm{AI}(\mathrm{n}=767 ; P=0.36)$. There was no overall relationship between sire net merit (\$) and first $\mathrm{AI} P / \mathrm{AI}(\mathrm{n}=695 ; P=0.21)$.

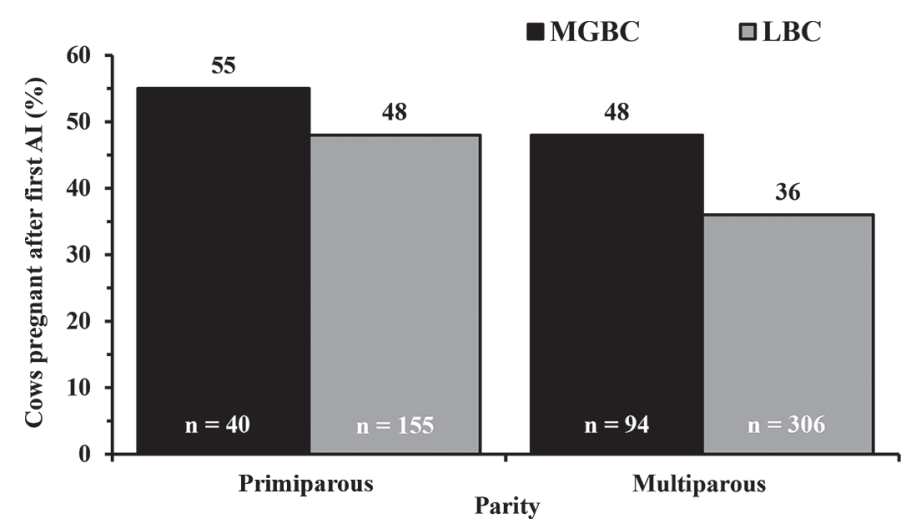

Figure 4. Percentage of primiparous and multiparous lactating Holstein dairy cows diagnosed pregnant $35 \mathrm{~d}$ after first AI that maintained or gained body condition (MGBC; $\mathrm{n}=146$ ) or lost body condition (LBC; $\mathrm{n}=500$ ) during the first 30 DIM. Cows that experienced at least 1 health event were not considered in the analyses. Significance between combinations of body condition change classes and parity was as follows: primiparous MGBC versus primiparous $\mathrm{LBC}, P=0.45$; multiparous $\mathrm{MGBC}$ versus multiparous $\mathrm{LBC}, P=0.04$; primiparous MGBC versus multiparous MGBC, $P=0.44$; primiparous LBC versus multiparous LBC, $P=0.01$; primiparous $\mathrm{MGBC}$ versus multiparous LBC, $P=0.02$; primiparous LBC versus multiparous MGBC, $P=$ 0.94 . 


\section{Relationship Between Body Condition Variables and Pregnancy Loss}

Cows that lost body condition during the first 30 DIM experienced greater pregnancy loss between 35 and 60 $\mathrm{d}$ after first AI compared with cows that maintained or gained body condition during that period (Table 1) regardless of whether cows with health events were considered. Carvalho et al. (2014) reported no difference in pregnancy loss rates from 40 to $70 \mathrm{~d}$ among classes of body condition change but did report a greater chance for degenerated embryos for cows that lost more body condition during the first 21 DIM. López-Gatius et al. (2002) and Santos et al. (2009) both reported an increased risk of pregnancy loss associated with body condition loss. This relationship was not found for later gestation pregnancy diagnoses following first AI or for second and greater AI regardless of time of pregnancy diagnoses (Table 1). Of all cows that experienced pregnancy loss between 35 and $60 \mathrm{~d}$ after AI, 21 of 26 were multiparous cows. Santos et al. (2009) reported that multiparous cows were more likely to lose a pregnancy than primiparous cows, although other studies indicate that there is no difference between parities and pregnancy loss (Yousuf et al., 2016; Martins et al., 2017,
2018). There was no relationship between BCS at 30 DIM and early pregnancy loss $(P=0.50 ; \mathrm{n}=431)$. These data continue to support the argument for a highfertility cycle. Cows that have more body condition loss in early lactation have a greater chance of pregnancy loss that eventually places these cows at greater risk of not being pregnant before 130 DIM.

\section{Relationships Between Body Condition Change During First 30 DIM and Periparturient Health Events}

There was a significant relationship between body condition loss and the occurrence of at least 1 periparturient health disorder of the 7 that were measured (RP, twins, dystocia, ketosis, displaced abomasum, pyometra, metritis $)$ in both primiparous $(\mathrm{n}=262 ; P=0.02)$ and multiparous $(\mathrm{n}=525 ; P=0.003)$ cows. There was a relationship between the amount of body condition cows lost in the first 30 DIM and the chance for experiencing at least 1 health event (Figure 6). Cows that maintained or gained $(\mathrm{n}=158)$ body condition had fewer single (6 vs. $13 \%$; $P=0.02$ ) and multiple (1 vs. $7 \% ; P=0.002)$ periparturient health events compared with cows that lost body condition $(\mathrm{n}=629)$ during

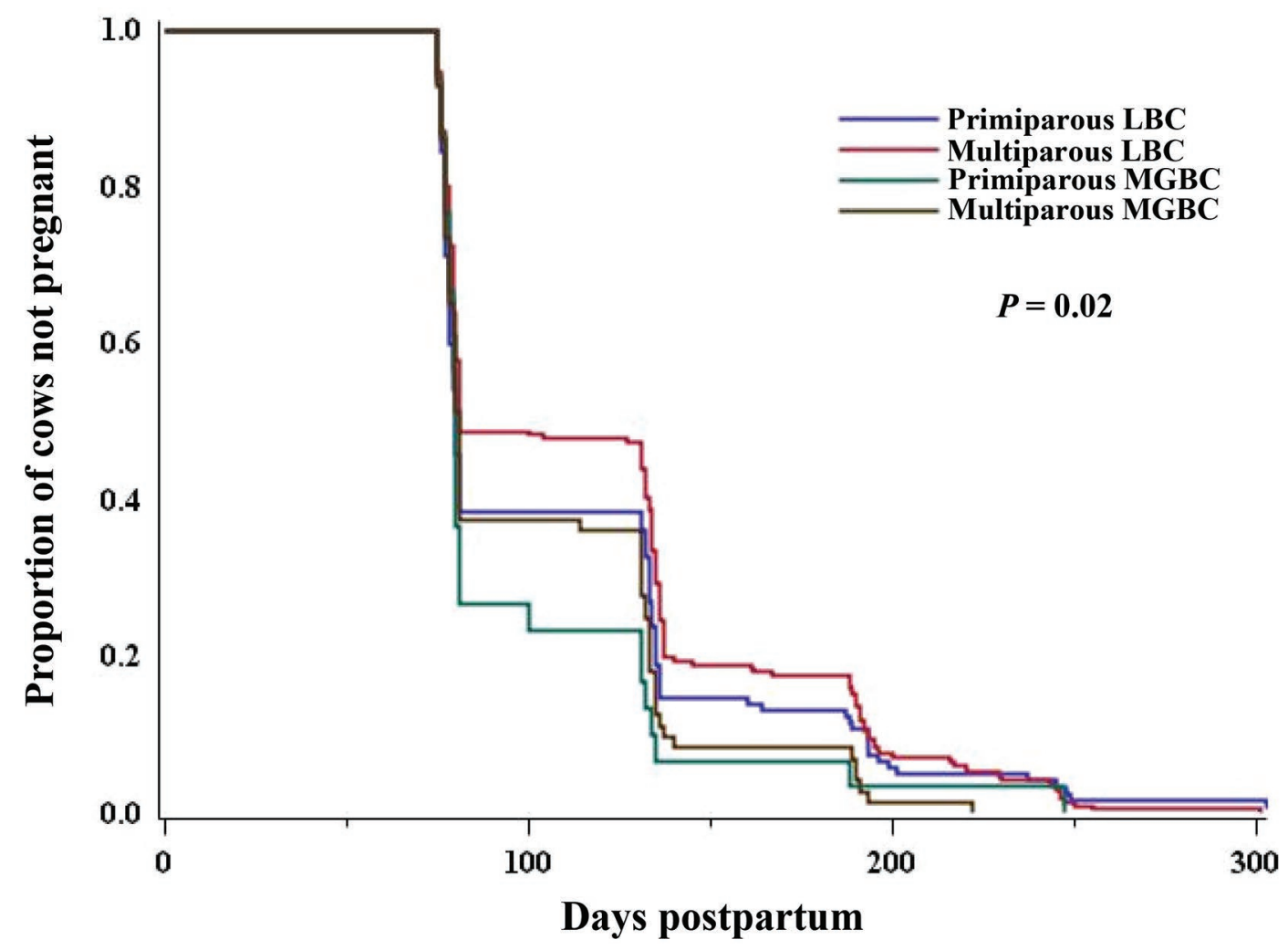

Figure 5. Survival curve estimates for the effect of body condition change on days to pregnancy for primiparous and multiparous lactating Holstein dairy cows $(n=435)$ that maintained or gained body condition (MGBC) or lost body condition (LBC) during the first 30 DIM. 


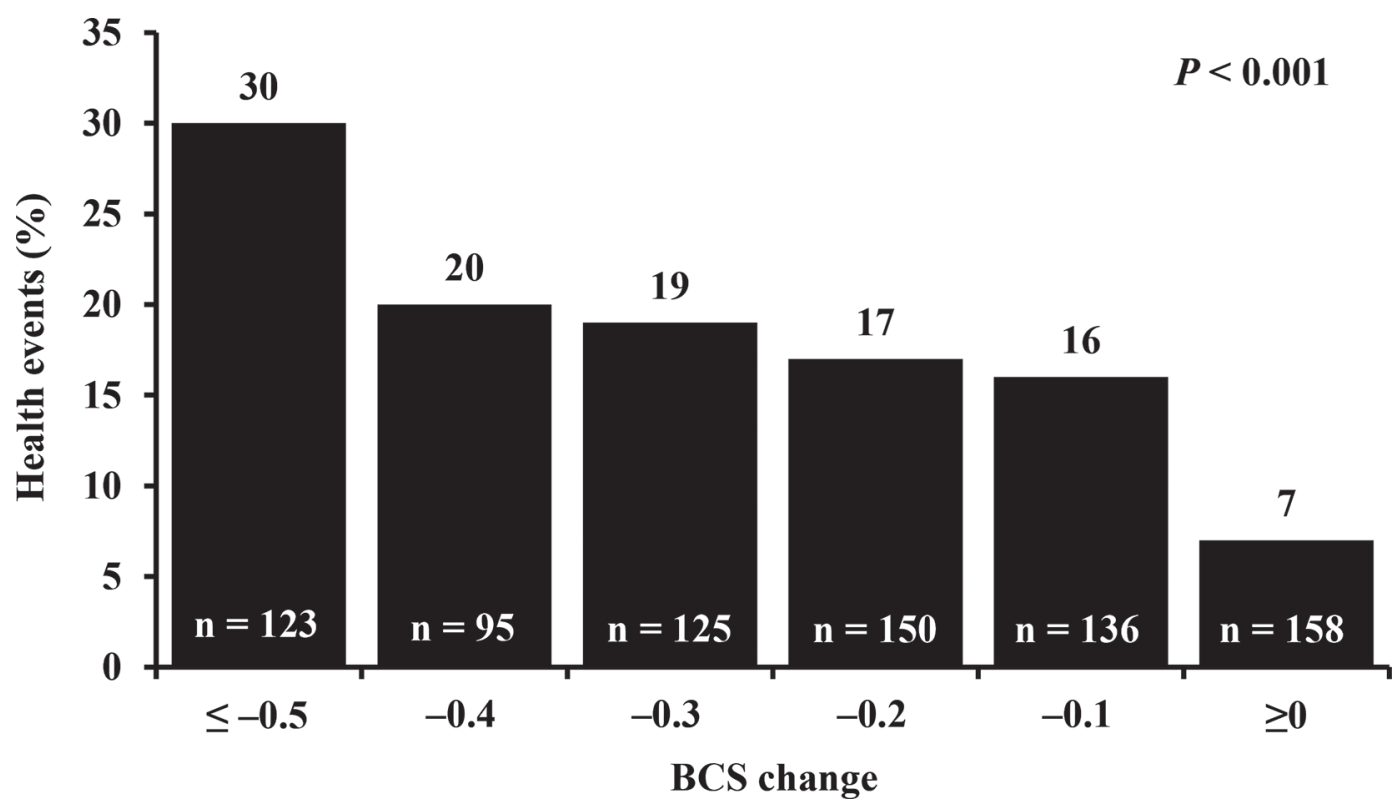

Figure 6. Percentage of primiparous and multiparous lactating Holstein dairy cows that experienced at least 1 periparturient health event within classes of body condition change during the first 27 to 33 DIM. There was no difference in percentage of health events in primiparous or multiparous cows $(P=0.08)$.

the first 30 DIM. However, the proportion of cows in the LBC group did not change when cows with at least 1 periparturient event were removed ( 80 vs. $77 \% ; P>$ 0.10). Ruegg and Milton (1995) also reported a higher incidence of diseases in cows that lost body condition.

Cows with RP and twins had greater chances for more body condition loss ( $\mathrm{n}=787 ; P=0.05$ and $P<0.01$, respectively). Greater body condition loss was related to incidences of ketosis $(\mathrm{n}=787 ; P=0.003)$, displaced abomasum $(P<0.01)$, and metritis $(P<0.01)$. There was no relationship between dystocia and subsequent body condition loss ( $\mathrm{n}=787 ; P=0.18$ ), contrary to the findings published by Berry et al. (2007b).

There was no relationship between the presence of bovine leukemia virus and class of body condition change $(\mathrm{n}=449 ; P=0.55)$ or the occurrence of a periparturient health event $(P=0.17)$. Also, there was no relationship between presence of Johne's disease and class of body condition change $(\mathrm{n}=447 ; P=0.09)$.

Cows with lower body condition at parturition had a greater predicted probability of twins $(\mathrm{n}=787 ; P$ $=0.04)$. The twinning rate was $3.0 \%$ for primiparous

Table 1. Relationship [\% (no./no.)] between body condition change ${ }^{1}$ during the first 30 DIM and pregnancy loss in dairy cows ${ }^{2}$ diagnosed pregnant at $35 \mathrm{~d}$ post-AI

\begin{tabular}{lccc}
\hline Item $^{3}$ & MGBC & LBC & $P$-value \\
\hline Pregnancy losses after first AI & & & \\
35-60 d post-AI & $0.0(0 / 64)$ & $8.2(15 / 183)$ & 0.02 \\
61-119 d post-AI & $9.4(6 / 64)$ & $3.6(6 / 168)$ & 0.08 \\
>120 d post-AI & $5.2(3 / 58)$ & $2.5(4 / 162)$ & 0.32 \\
Pregnancy losses after second AI & $3.1(1 / 32)$ & $7.8(10 / 128)$ & 0.35 \\
35-60 d post-AI & $3.2(1 / 31)$ & $5.1(6 / 118)$ & 0.66 \\
61-119 d post-AI & $0.0(0 / 30)$ & $5.4(6 / 112)$ & 0.20 \\
$>120$ d post-AI &
\end{tabular}

${ }^{1} \mathrm{MGBC}=$ cows maintained or gained body condition $(\mathrm{n}=146) ; \mathrm{LBC}=$ cows lost body condition $(\mathrm{n}=500)$. ${ }^{2}$ Cows that experienced at least 1 health event were not considered in the analyses for first AI only. When cows with at least 1 health event were considered for first AI pregnancy losses, $P$-values were 35 to $60 \mathrm{~d}, P=0.02$; 61 to $119 \mathrm{~d}, P=0.07$; and $>120 \mathrm{~d}, P=0.36$. Twenty-one of 26 cows that lost pregnancies between 35 and 60 $\mathrm{d}$ after first and second AI were multiparous cows. There was no effect of parity on pregnancy losses after first AI $(P=0.51)$ or second AI $(P=0.46)$.

${ }^{3}$ Cows that were culled or died before pregnancy diagnoses at 60 or $119 \mathrm{~d}$ post-AI or from $120 \mathrm{~d}$ post-AI to parturition were removed from this calculation. 
and $7.0 \%$ for multiparous cows. There was no relationship between body condition at parturition and the incidence of at least 1 periparturient health event $(\mathrm{n}=$ $787 ; P=0.54)$. In contrast, greater body condition at calving was associated with a greater risk of periparturient health events (Gillund et al., 2001). Gearhart et al. (1990) and Ruegg and Milton (1995) did not find relationships between body condition at parturition and incidence of periparturient health events.

Higher body condition at parturition was not associated with greater incidences of dystocia and metritis (n $=787 ; P=0.24$ and $P=0.61$, respectively). Berry et al. (2007b) did not find a relationship between dystocia and body condition at parturition. There was a relationship between body condition at 30 DIM and the occurrence of at least 1 periparturient health event $(P$ $=0.001 ; \mathrm{n}=787$ ). It seems logical that health events would have a negative consequence on body condition at 30 DIM, although when disease was accounted for in the model, it did not change the proportion of cows in the body condition change groups. However, one thing to consider in this study in this single herd is the limited statistical power with only 787 cows, of which only $19 \%$ had at least 1 health event.

There was a relationship between the birth of twins and chances for dystocia and displaced abomasum. Cows that gave birth to twins had a greater chance for dystocia $(P<0.01)$ and displaced abomasum $(P=$ $0.002)$. Month of parturition predicted $(P=0.001)$ periparturient health events $(\mathrm{n}=851)$. Cows that calved during the first $5 \mathrm{mo}$ of the year had a greater chance of at least 1 periparturient health event. This coincides with the months during which cows are more likely to lose body condition. Cows that experienced at least 1 periparturient health event had lower $(P<0.001)$ milk production at 30 DIM $(41.9 \pm 1.4$ vs. $46.5 \pm 2.5 \mathrm{~kg} /$ cow per day; $\pm \mathrm{SEM} ; \mathrm{n}=719)$ but not $(P=0.84)$ at 60 DIM ( $45.8 \pm 2.8$ vs. $46.1 \pm 1.6 \mathrm{~kg} /$ cow per day; \pm SEM; $\mathrm{n}=684$ ) compared with cows that did not have at least 1 periparturient health event.

There was no relationship between the occurrence of at least 1 periparturient health event and first AI P/AI $(\mathrm{n}=767 ; P=0.15)$. There also was no relationship between the presence of bovine leukemia virus or Johne's disease and first AI P/AI $(\mathrm{n}=423, P=0.47$ and $\mathrm{n}=$ $420, P=0.82$, respectively). Domecq et al. (1997) did not find a relationship between periparturient health events and $\mathrm{P} / \mathrm{AI}$.

There was no relationship between the occurrence of a single periparturient health event and early pregnancy loss $(\mathrm{n}=552 ; P=0.41)$. López-Gatius et al. (2002) also did not detect a relationship between cow health and subsequent pregnancy loss between 38 and $90 \mathrm{~d}$.

\section{Relationship Between Previous Gestation Length, Body Condition, and Fertility}

There was a correlation between previous gestation length and body condition change but not body condition at parturition $(\mathrm{n}=851 ; P=0.93)$. Cows with longer previous gestation length had a greater probability ( $\mathrm{n}=724 ; P=0.01$ ) of body condition loss during the first 30 DIM. Longer gestation lengths were associated with lower $\mathrm{P} / \mathrm{AI}$ at first AI $(\mathrm{n}=735 ; P=0.02)$. Interestingly, there was a lack of a relationship between gestation length and chances for dystocia in singleton births $(\mathrm{n}=731 ; P=0.85)$. It was unclear why longer previous gestation lengths are associated with greater body condition loss and lower P/AI at first AI but not greater instances of dystocia. There was no relationship between time of pregnancy in previous lactation and subsequent gestation length $(\mathrm{n}=496 ; P=0.72)$. Shorter previous gestation lengths were associated with a higher incidence of periparturient health events $(\mathrm{n}=$ $771 ; P=0.05)$, twin births $(\mathrm{n}=771 ; P<0.01)$, and greater chances for displaced abomasum $(\mathrm{n}=771 ; P$ $=0.03)$.

\section{Relationship Between Body Condition Loss During First 30 DIM and Subsequent Sex Ratio at Birth}

Sex ratio at parturition following first and subsequent AI for singleton calves was $53 \%$ male and $47 \%$ female (n $=466$ ). This was similar to previously reported secondary sex ratios (Ryan and Boland, 1991; Roche et al., 2006). When the MGBC and LBC groups were analyzed separately in cows that had both BCS (parturition and 30 DIM), there was a relationship in the LBC group between the extent of body condition that was lost and the subsequent sex of the calf $(\mathrm{n}=346 ; P=0.04)$. The probability of a male decreased as cows lost more body condition (Figure 7). In the MGBC group, there was a tendency for more male calves born as cows gained more body condition $(\mathrm{n}=91 ; P=0.12)$. There was no relationship between the occurrence of a single periparturient health event and the subsequent sex of calf (n $=466 ; P=0.93)$. Trivers and Willard (1973) hypothesized that sex ratio at birth is influenced by maternal condition in species where reproductive success varies between sexes. In this case we have defined maternal condition in terms of the amount of body condition lost following parturition. This hypothesis has been applied to dairy cows (Roche et al., 2006). Cows with greater body condition at conception or cows that experienced less loss were viewed as being in greater maternal condition. These cows have a sex ratio at birth skewed toward male calves. Cows with low body condition at conception or greater body condition loss would have 


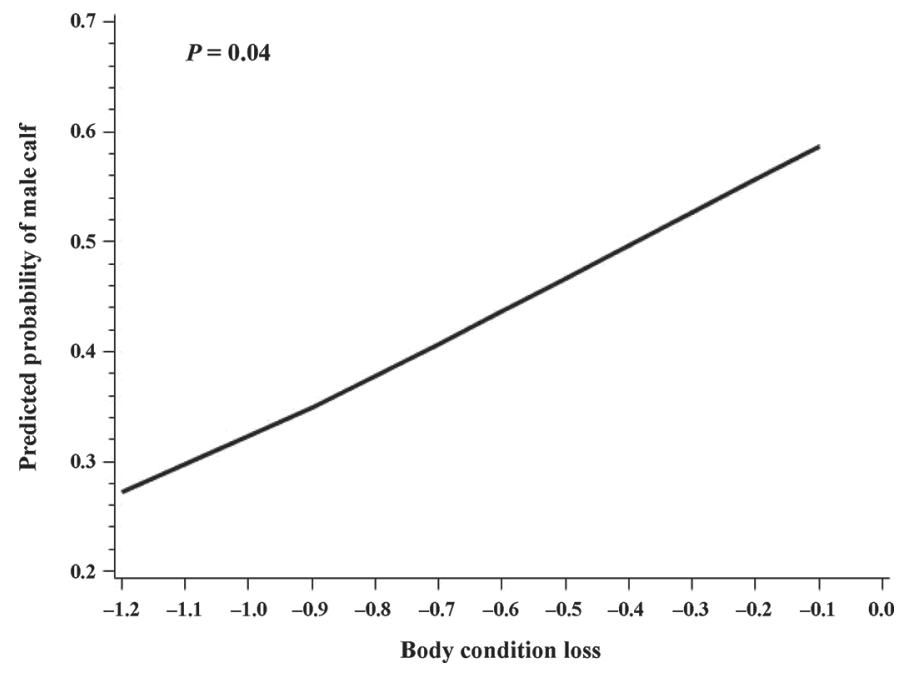

Figure 7. Predicted probability of a male calf based on extent of body condition lost from $\leq 1 \mathrm{wk}$ of parturition to 27 to $33 \mathrm{~d}$ postpartum in only the group of primiparous and multiparous lactating Holstein cows that lost body condition $(\mathrm{n}=346)$.

a sex ratio skewed toward female calves. Roche et al. (2006) found that body condition at conception did not influence sex ratio at birth, but cows that had less loss or gained body condition had a greater number of bull calves. Our data supported these findings and partially support the Trivers-Willard hypothesis. Greater body condition loss was indicative of poor maternal condition and skewed the sex ratio at birth to fewer male calves born. There was very little homogeneity of body condition change in the maintained and gained group of cows to evaluate for skewing of sex ratio.

\section{Summary}

These data lead to a greater understanding of how length of previous lactations leads to variability in body condition at parturition, body condition change in early lactation, and subsequent fertility in this single herd of cows. Cows that become pregnant before 130 DIM have a greater chance of maintaining or gaining body condition during the first $30 \mathrm{~d}$ of the subsequent lactation, leading to a greater chance of pregnancy and a reduced chance of pregnancy loss from 35 to $60 \mathrm{~d}$ post-AI. This leads to greater chances of maintaining a cycle of pregnancy before 130 DIM. Based on data in this study, maintaining a cycle of pregnancy before 130 DIM will likely enhance P/AI at first and subsequent AI and reduce the possibility of early pregnancy loss. We now refer to this potential phenomenon as the highfertility cycle. Utilizing fertility programs at first AI and controlling time to subsequent inseminations can help accomplish this. However, it is also critical to de- tect nonpregnant cows as soon as possible and ensure a timely resynchronized timed AI to enable cows' chances of becoming pregnant before 130 DIM.

Reducing the chances for body condition loss at parturition also reduces the chances of periparturient health disorders. Although it did not appear that cows with health issues had reduced chances for pregnancy, maintaining a high-fertility cycle may reduce peripartum health disorders. Finally, we repeated previously published data in dairy cows that partially support the Trivers-Willard hypothesis. Cows that maintained or gained body condition during the first 30 DIM appear to be more apt to pass along their genes through more male calves. Unfortunately, dairy producers only genetically select for females that of course have greater chances of being born from cows with more health issues. The relationship between cows that gain too much body condition during gestation and fetal development or the effect of body condition loss on subsequent oocyte competence is not well understood in dairy cows.

\section{ACKNOWLEDGMENTS}

E. L. Middleton's funding for this project was made possible by grants from the College of Agriculture and Natural Resources Undergraduate Research Program (Michigan State University; East Lansing) and the Michigan Alliance for Animal Agriculture (East Lansing). We especially thank Ken and Kerry Nobis and all the employees at Nobis Dairy Farm (St. Johns, MI) for their assistance and use of their cows. We also thank Lindsey Baird and Michael Herman, undergraduate research assistants (Michigan State University; East Lansing), for their roles in this project as well as Parnell Animal Health (Overland Park, KS) for donating the GONAbreed and estroPLAN used for G6G/Ovsynch at Nobis Dairy Farm.

\section{REFERENCES}

Bello, N. M., J. P. Steibel, and J. R. Pursley. 2006. Optimizing ovulation to first GnRH improved outcomes to each hormonal injection of Ovsynch in lactating dairy cows. J. Dairy Sci. 89:3413-3424.

Berry, D. P., F. Buckley, and P. Dillon. 2007a. Body condition score and live-weight effects on milk production in Irish Holstein-Friesian dairy cows. Animal 1:1351-1359.

Berry, D. P., J. M. Lee, K. A. Macdonald, and J. R. Roche. 2007b. Body condition score and body weights on dystocia and stillbirths and consequent effects on postcalving performance. J. Dairy Sci. 90:4201-4211.

Berry, D. P., R. F. Veerkamp, and P. Dillon. 2006. Phenotypic profiles for body weight, body condition score, energy intake, and energy balance across different parities and concentrate feeding levels. Livest. Sci. 104:1-12.

Britt, J. H. 1985. Enhanced reproduction and its economic implications. J. Dairy Sci. 68:1585-1592.

Britt, J. H. 1992. Impacts of early postpartum metabolism on follicular development and fertility. Bovine Practitioner Proc. 24:39-43. 
Carvalho, P. D., A. H. Souza, M. C. Amundson, K. S. Hackbart, M. J. Fuenzalida, M. M. Herlihy, H. Ayres, A. R. Dresch, L. M. Vieira, J. N. Guenther, R. R. Grummer, P. M. Fricke, R. D. Shaver, and M. C. Wiltbank. 2014. Relationships between fertility and postpartum changes in body condition and body weight in lactating dairy cows. J. Dairy Sci. 97:3666-3683.

Curran, S. 1992. Fetal sex determination in cattle and horses by ultrasonography. Theriogenology 37:17-21.

De Vries, A., J. D. Olson, and P. J. Pinedo. 2010. Reproductive risk factors for culling and productive life in large dairy herds in the eastern United States between 2001 and 2006. J. Dairy Sci. 93:613-623.

de Vries, M. J., and R. F. Veerkamp. 2000. Energy balance of dairy cattle in relation to milk production variables and fertility. J. Dairy Sci. 83:62-69.

Dijkhuizen, A. A., J. Stelwagen, and J. A. Renkema. 1984. Economic aspects of reproductive failure in dairy cattle. I. Financial loss at farm level. Prev. Vet. Med. 3:251-263.

Dohoo, I. R., and S. W. Martin. 1984. Disease, production and culling in Holstein-Friesian cows: III. Disease and production as determinants of disease. Prev. Vet. Med. 2:671-690.

Domecq, J. J., A. L. Skidmore, J. W. Lloyd, and J. B. Kaneene. 1997. Relationship between body condition scores and conception at first artificial insemination in a large dairy herd of high yielding Holstein cows. J. Dairy Sci. 80:113-120.

Edmondson, A. J., I. J. Lean, L. D. Weaver, T. Farver, and G. Webster. 1989. A body condition scoring chart for Holstein dairy cows. J. Dairy Sci. 72:68-78.

Fricke, P. M. 2002. Scanning the future - Ultrasonography as a reproductive management tool for dairy cattle. J. Dairy Sci. 85:19181926.

Gearhart, M. A., C. R. Curtis, H. N. Erb, R. D. Smith, C. J. Sniffen, L. E. Chase, and M. D. Cooper. 1990. Relationship of changes in condition score to cow health in Holsteins. J. Dairy Sci. 73:31323140.

Gillund, P., O. Reksen, Y. T. Gröhn, and K. Karlberg. 2001. Body condition related to ketosis and reproductive performance in Norwegian dairy cows. J. Dairy Sci. 84:1390-1396.

Giordano, J. O., P. Fricke, and V. E. Cabrera. 2013. Economics of resynchronization strategies including chemical tests to identify nonpregnant cows. J. Dairy Sci. 96:949-961.

Heuer, C., Y. H. Schukken, and P. Dobbelaar. 1999. Postpartum body condition score and results from test day milk as predictors of disease, fertility, yield, and culling in commercial dairy herds. J. Dairy Sci. 82:295-304.

López-Gatius, F., P. Santolaria, J. Yániz, J. Rutllant, and M. LópezBéjar. 2002. Factors affecting pregnancy loss from gestation day 38 to 90 in lactating dairy cows from a single herd. Theriogenology 57:1251-1261.

Martins, J. P. N., M. J. T. Acevedo, T. O. Cunha, C. Piterini, and J. R. Pursley. 2017. The effect of presynchronization with prostaglandin F $2 \alpha$ and gonadotropin-releasing hormone simultaneously, $7 \mathrm{~d}$ before Ovsynch, compared with Presynch-10/Ovsynch on luteal function and first-service pregnancies per artificial insemination. J. Dairy Sci. 100:5107-5116.

Martins, J. P. N., D. Wang, N. Mu, G. F. Rossi, A. P. Martini, V. R. Martins, and J. R. Pursley. 2018. Level of circulating concentra- tions of progesterone during ovulatory follicle development affects timing of pregnancy loss in lactating dairy cows. J. Dairy Sci. 101:10505-10525.

Meadows, C. 2005. Reproductive record analysis. Vet. Clin. North Am. Food Anim. Pract. 21:305-323.

Moreira, F., C. Risco, M. F. A. Pires, J. D. Ambrose, M. Drost, M. DeLorenzo, and W. W. Thatcher. 2000. Effect of body condition on reproductive efficiency of lactating dairy cows receiving a timed insemination. Theriogenology 53:1305-1319.

Morris, R. S. 1971. Economic aspects of disease control programmes for dairy cattle. Aust. Vet. J. 47:358-363.

NRC. 2001. Nutrient Requirements of Dairy Cattle. 7th rev. ed. Natl. Acad. Sci., Washington, DC.

Pryce, J. E., M. P. Coffey, and S. Brotherstone. 2000. The genetic relationship between calving interval, body condition score and linear type and management traits in registered Holsteins. J. Dairy Sci. 83:2664-2671.

Pryce, J. E., M. P. Coffey, and G. Simm. 2001. The relationship between body condition score and reproductive performance. J. Dairy Sci. 84:1508-1515.

Ribeiro, E. S., F. S. Lima, F. Greco, R. S. Bisinotto, A. P. A. Monteiro, M. Favoreto, H. Ayres, R. S. Marsola, N. Martinez, W. W. Thatcher, and J. E. P. Santos. 2013. Prevalence of periparturient diseases and effects on fertility of seasonally calving grazing dairy cows supplemented with concentrates. J. Dairy Sci. 96:5682-5697.

Roche, J. R., D. P. Berry, J. M. Lee, K. A. Macdonald, and R. C. Boston. 2007. Describing the body condition score change between successive calvings: A novel strategy generalizable to diverse cohorts. J. Dairy Sci. 90:4378-4396.

Roche, J. R., J. M. Lee, and D. P. Berry. 2006. Pre-conception energy balance and secondary sex ratio-Partial support for the TriversWillard hypothesis in dairy cows. J. Dairy Sci. 89:2119-2125.

Ruegg, P. L., and R. L. Milton. 1995. Body condition scores of Holstein cows on Prince Edward Island, Canada: Relationships with yield, reproductive performance, and disease. J. Dairy Sci. 78:552-564.

Ryan, D. P., and M. P. Boland. 1991. Frequency of twin births among Holstein-Friesian cows in a warm dry climate. Theriogenology $36: 1-10$.

Santos, J. E. P., H. M. Rutigliano, and M. F. Sá Filho. 2009. Risk factors for resumption of postpartum estrous cycles and embryonic survival in lactating dairy cows. Anim. Reprod. Sci. 110:207-221.

Shahid, M. Q., J. K. Reneau, H. Chester-Jones, R. C. Chebel, and M. I. Endres. 2015. Cow- and herd-level risk factors for on-farm mortality in Midwest US dairy herds. J. Dairy Sci. 98:4401-4413.

Souza, A. H., H. Ayres, R. M. Ferreira, and M. C. Wiltbank. 2008. A new presynchronization system (Double-Ovsynch) increases fertility at first postpartum timed AI in lactating dairy cows. Theriogenology 70:208-215.

Trivers, R. L., and D. Willard. 1973. Natural selection of parental ability to vary the sex ratio of offspring. Science 179:90-92.

Villa-Godoy, A., T. L. Hughes, R. S. Emery, L. T. Chapin, and R. L. Fogwell. 1988. Association between energy balance and luteal function in lactating dairy cows. J. Dairy Sci. 71:1063-1072.

Yousuf, M. R., J. P. N. Martins, N. Ahmad, K. Nobis, and J. R. Pursley. 2016. Presynchronization of lactating dairy cows with $\mathrm{PGF}_{2 \alpha}$ and GnRH simultaneously, 7 days before Ovsynch have similar outcomes compared to G6G. Theriogenology 86:1607-1614. 